\title{
Democratic Participation
}

\section{Shanti P. Chakravarty ${ }^{1}$}

Received: 31 December 2017 / Accepted: 27 June 2018 / Published online: 7 July 2018

(c) The Author(s) 2018

\begin{abstract}
Democracy is not just about the choice of policy determined by the aggregation of ballots cast in elections. It is also about managing tensions which may arise between proclaimed virtues of democratic values and the vicissitudes of public opinion. Further, a conundrum arises because it is not for the electorate to spend time and energy acquiring specialist knowledge about the efficacy of action, but the voters expect to be consulted on policy. It is a lofty ideal of democracy that the electorate can hold government responsible for adverse outcomes not expected by the voters when casting their ballots on policy. Resort to referendums does not necessarily resolve these contradictory demands of democracy, but it can amplify them.
\end{abstract}

Keywords Participatory democracy $\cdot$ Election $\cdot$ Referendum $\cdot$ Dangers to democracy

JEL Codes D02 $\cdot$ D70 $\cdot \mathrm{H} 10 \cdot \mathrm{H} 19$

\section{Introduction}

Democracy is a contested idea, but there is a consensus which can form a basis for discussion (Frey 2017, p. 3): "A basic idea of democracy is that people being affected by political decisions have a say." Survey reports suggesting that support for democracy has declined in Europe following the financial meltdown in 2007 are concerning (Armingeon and Guthmann 2014, Table 2, p. 432). Concern has been expressed in Britain about low rates of participation, especially of the young, in elections: "We believe that improving voter engagement is crucial to the long term

Section III in the text draws closely on arguments I have made earlier in this journal (Chakravarty 2008), as noted in Footnote 3.

Appendix B draws closely on arguments which appear in a blog on Brexit which I had written following the Brexit referendum.

Shanti P. Chakravarty

s.p.chakravarty@bangor.ac.uk

1 Business School, Bangor University, Bangor, Gwynedd LL57 2DG, UK 
well-being of democracy in the UK" (House of Commons 2014, p. 3). Some of these discussions lead to a recommendation for direct participation by the electorate in policy making. Our contention is that recommendations for resort to referendums to improve public engagement with the democratic process are misleading.

The House of Lords Select Committee on the Constitution in its $12^{\text {th }}$ Report invited submissions from constitutional scholars some of whom recommended resort to referendums to increase public engagement with the political system (House of Lords 2010, p. 13). Bruno Frey extols the virtue of the Swiss system of participatory democracy (Frey 2017, 1994). Citing happiness indices, he claims that voters in Switzerland feel engaged with decisions which affect them by being able to vote in local referendums. Pursuing this line of analysis, he calls this the public choice approach, Frey has prescriptions about improving the quality of the democratic process, for example by extending the right to franchise to non-citizens who have made a home in the country. The main thrust of his recommendations is the Swiss Style voter engagement through referendums. We suggest that something important is missing in this line of enquiry based on the rational choice approach using the tools of utilitarian economics. There is no examination of the information content of choice sets and there is no discussion of values that provide moral legitimacy to the choice that is made. This is a point raised in the seminal work by Arrow (1963) on individual choice and social values, but it is a point which is mostly neglected in the public choice literature.

This paper is organized as follows. Section 2 outlines the poverty of the exclusive focus on elections in the economic approach to the analysis of democracy. Section 3 discusses the background of economic change leading to changes in political institutions. Section 4 considers the dangers to democracy of majority rule. Section 5 highlights the tension between the rule of law and vicissitudes of public opinion as it impacts on individual liberty. Section 6 points to the challenge for democracy in truncating the choice set to address the above problem and to obtain consensus. Section 7 highlights a concern about the length of the period of remit of referendums. One of the purposes of changing government through the ballot box in a democracy is to cater for the potential disconnect between ex ante choice of policy and ex post judgement by the electorate of the desirability of the outcome of that choice. Referendums, especially when they are perceived as popular mandates which run beyond normal electoral cycles, fail to meet that purpose which is essential to democracy. Section 8 continues with that theme to argue that resort to referendums is a confession of failure in a democracy. Section 9 concludes.

\section{Political Expectations of Democracy}

There are various manifestations of the idea of democracy as people "having a say" (Frey 2017, p. 3) in how they are governed. For example, democracy might be construed as a particular "type of a social structure and as a set of political expectations" (Mills 1977, p. 130). In the public choice literature in politics, these expectations are examined using the tools of utilitarian neo-classical economics. The assumption is 
that individuals maximize their preferences over policies in voting decisions. ${ }^{1}$ One line of enquiry in this tradition has been the search for the properties of voting rules because "difficulties in aggregating preferences [of voters] arise in the case of a population with a lack of a consensus... [and] the choice of electoral system can make the greatest difference... where apparently minor differences can directly influence the outcome" (Levin and Nalebuff 1995, p. 4). ${ }^{2}$

To make matters more difficult, voters themselves aggregate over policies, but polling data suggests that their choice of parties is not always commensurate with their views on a range of policies. For example, a majority of those that identified with Labour supported the Conservative policy of reduction in the higher rate of income tax in the 1979 general election (Leonard and Mortimore 2001, Table 13.3.3, p. 180). A major study of the British electorate found that the support base for both Labour and Conservative parties was becoming less committed to their respective party's policies (Särlvik and Crewe 1983). Disconnect between support for a presidential candidate and a wide range of policy issues has also been reported in the United States (Chomsky 2006, p. 215). The choice made by the voter begins to lose clarity. These difficulties of aggregation provide temptations to galvanize political participation through single issue referendums. However, the quality of democracy is not enhanced by increasing enthusiasm to make the effort to turn up at the polling booth by putting complex and contentious issues for adjudication by the electorate in referendums.

The ideals of democracy, for example enabling the flourishing of ideas through tolerance of diversity and rational discourse over differences, which confer legitimacy on democratic decisions, require liberty to explore and propagate views. A singular focus on choice without consideration of checks and balances needed to protect democracies from intolerance of ideas is inadequate for preserving and enhancing the ideals of democracy. This is also inadequate because reasoned choice itself requires scrutiny of the circumstances under which the right to choose is exercised.

A focus on giving an ever more list of topics one at a time for voters to make binary decisions misses the need for reasoned choice. The idea that the purpose of democracy is to enact into legislation the wishes of the electorate as gleaned from voting data ignores many important issues raised in the social choice literature. There is information deficiency in ascertaining preferences by vote counting alone without supplementing the data with additional information (Sen 1973). In a telling phrase, one of the most distinguished scholars to provide inspirations for rational choice political theory makes a distinction between values that individuals hold and the 'tastes' which might enter a utility function (Arrow 1963, p. 23). Taste, as that word is used in utilitarian economics, can be whimsical. For example, Becker calls an arbitrary dislike of people because of their gender or skin colour the

\footnotetext{
${ }^{1}$ Downs (1957) broadened the discussion to postulate that politicians and political parties choose policies to maximize their chance of winning elections.

2 Many voting paradoxes have been studied in the literature (Forder 2011: 44; Fishburn 1974; Woodall 1987; Nurmi 1998). See Appendix A for a discussion.
} 
manifestation of a taste for discrimination against those people (Becker 1973). Values require greater thought. I value privacy is a statement of a reasoned preference than the declaration that I have a taste for privacy. Democracy is not legitimized simply by participation in franchise for the recording of voters' tastes. For the exercise of voting to confer democratic legitimacy on governance, it needs to be examined if the circumstances surrounding that act fostered freedom of discussion and debate to arrive at a reasoned view. The distinction between tastes and values is not easy to make in a formal model of voting, but that does not absolve us from looking at "the entire system of values, including values about values, in seeking for a truly general theory of social welfare" (Arrow 1963, p. 18). This point is further elaborated upon in the literature on rationality and freedom (Sen 2002, p. 6).

Complex issues require detailed examination, and some of these issues are best dealt with through deliberations of elected representatives. Our contention is that resort to referendums can exacerbate the problems for democracy by over-simplification of issues. This tension manifests itself starkly in discourses on criminal justice, patriotism, national identity, and human rights.

\section{Emergence of a New Political Doctrine}

We begin our discussion not with an analysis of Athenian democracy in antiquity, but with a description of a more recent occurrence, the transition from agriculture to industry. ${ }^{3}$ The sovereignty of the state is "contingent upon our agreement to [the] exercise" of power by the state over its citizens (Laski 1962, p. 23). Consent of the public in the feudal system characterising agrarian societies derived from the legitimacy to rule enjoyed by the monarch. Authority in feudal societies derived from a stable system of hierarchies, based on faith and fear, as the twentieth century economist Keynes was to explain. Power was vested in the monarch by deities that all revered and feared. There was a symbiotic relationship between the clergy and the Crown to reinforce faith and inculcate fear. ${ }^{4}$ There were promised rewards in afterlife for unquestioning acceptance of misery while alive.

That bargain began to be perceived as less attractive, as religion began to lose its grip with the social upheavals of industrialization, than the quest by the masses for a better existence in this life. This quest eventually led to the emergence of an element of electoral input in the design of institutions of governance. The rulers needed to claim new forms of legitimacy in the exercise of power when piety alone would not suffice. Movements for democracy to succeed, the hold of religion had to weaken to disentangle the spiritual from the temporal.

\footnotetext{
3 This section is taken from an earlier article of mine published in this journal (Chakravarty 2008).

4 When that symbiotic relationship between the clergy and the crown broke down, as it did in sixteenth century Britain between the Roman Catholic hierarchy and the King, battles ensued to establish a new religious order to confer God's approval of the monarch's exercise of power. Eventually, a new church with Henry as the Supreme Head would be established. It would be independent of Rome. Catholics would be regarded as a potential threat to the crown and needed to be excluded from power. Test Acts imposed disabilities on those that would not pass the test of "true belief".
} 
Industrial trends imposed changes in the hierarchy of authority by enriching some that did not inherit wealth, often initially bestowed by the monarch at some point in the past, and were not members of the established religion. As the grip of religion lessened, as we shall presently see, government was less fearful of religious dissent. For example, Catholics were allowed from 1829 to become members of parliament in Britain. Exercise of power was increasingly legitimised by money, even if that was new money.

Consider the sequence of events in England. By the mid-nineteenth century, rapid population movements occasioned by economic change following the industrial revolution reduced the hold of the clergy on the new working class. The clergy were often not there to inculcate belief in the moral superiority of the crown, and the distribution of wealth in the realm. A new concept of morality was called for.

"By modern standards the working classes and urban masses which grew up in the period of the Industrial Revolution were no doubt strongly influenced by religion; by the standards of the first half of the 19th century there was no precedent for their remoteness from, ignorance of, and indifference to, organised religion....[as the] British Religious Census of 1851 demonstrated it to the horror of contemporaries. Much of this remoteness was due to the utter failure of the traditional established churches to cope with agglomerations... the great cities and the new industrial settlements...and with social classes... the proletariat...which were foreign to their routines and experience. By 1851 , there were church places available for only 34 per cent of the inhabitants of Sheffield, only 31.2 per cent for those in Liverpool and Manchester, only 29 per cent of those in Birmingham. The problems of being a parish priest in an agricultural village were no guide to the cure of souls in an industrial town or urban slum.” (Hobsbawm 1962, p. 263).

Economic organisation has a bearing on the way political and civic institutions develop (Hirschman 1994; Lacroix 2017). The adaptive behaviour in a static feudal society of accepting one's externally determined position on the social ladder becomes disturbed by rapid economic change. "Improvements in conditions and observed social mobility can release people from adaptive preferences. Even if people still believe that the poor will always be with us, they may begin to ask why they [themselves] should be among them" (Elster 1989, p. 163). Electoral democracy as a process of conferring legitimacy of the exercise of power by those in authority is a product of changes in the economic system, transition from feudalism to capitalism, occasioned by the industrial revolution.

Feudal certainties having come into question in the wake of industrialisation, a secular justification of property rights was needed. The new rich, by making money through commerce and industry and not necessarily always by birth, developed a countervailing power against the landed gentry and their counterpart the rural clergy. The new capitalist rich could not be ignored.

The new ideology to legitimise the distribution of privileges under capitalism accompanying industrialisation was to promote the interest of the individual as the focus of analysis. A community was best organised if individuals could pursue their self-interest. "The purpose of promoting the individual was to depose the monarch 
and the church..." (Keynes1963, p. 273). Let us start with an early utilitarian, Jeremy Bentham. He put the utilitarian case bluntly:

"The community is a fictitious body, composed of the individual persons who are considered as constituting as it were its members. The interest of the community then is, what? - the sum of the interests of the several members who compose it." (quoted in Arblaster 1987, p. 65).

This Benthamite idea is encapsulated in Mishan's essay on Pareto efficiency in utilitarian political economy:

"...the welfare of each person in society is to count, and nothing more is to count. The phrase 'nothing more is to count' is appended to the sentence in order to obviate any 'transcendental' or 'holistic' interpretation of society's welfare. In no other words, no abstractions such as the 'general good' and no such entity as the 'state' is to be considered in addition to the welfare of the individuals comprising society.” (Mishan 1982, p. 33)

Viewed from the perspective of a Benthamite society, democracy becomes an exercise of aggregation of individual preferences expressed through the ballot box to articulate a view of the social choice. Insofar as different versions of capitalism emerged, so did emerge different institutional forms of democracy. But there were certain commonalities. Elections in some form extending rights to an increasing fraction of the population became an essential common ingredient. However, this Benthamite conception of society falls far short of what is needed to provide moral justification for democracy.

As it began to evolve, elections were viewed not just as a procedure for electing governments but, perhaps more importantly, as a means of impressing humility upon elected leaders. What elections could aim to do at the minimum was to hold out the threat that the rulers' tenure could be curtailed by the voters. In combination, but only in combination, with strong institutions endowed with power to challenge the elected leaders against the exercise of arbitrary power, elections could also hold back the emergence of an elected dictatorship.

\section{Will of the Majority}

The emergence of the utilitarian movement provided an early framework for a liberal society, but only as a negative idea of what it was not to be. It was not to be a dictatorship. There was no prescription to define and reconcile moral rights of the individual with the claims of society. Jeremy Bentham "thought that the idea of moral rights was "nonsense on stilts", (Dworkin 1970, p. 1). Utilitarians value individual rights only insofar as they contribute to the greater good of society. There is a right to equal treatment in that all votes, if social decisions are based on aggregation of votes cast by individuals, are to be treated equally. The literature on democracy which has developed from this tradition has placed focus on searching for the majority view, often justified by reference to the Condorcet Jury Theorem which has 
been discussed extensively in the literature (Ladha 1992). Much has been written about the mathematical and statistical properties of different ways of counting votes, and different concepts of the majority view. All voting systems are found to contain anomalies. "The chief relevant point here is that virtually every particular scheme proposed for election from single-member constituencies has been shown to have certain arbitrary features" (Arrow 1963, p. 6). It is time to move on the discussion beyond vote counting rules to elucidate the majority view. There are other aspects of improving the functioning of democracy which need attention. In any event, the majority per se does not have claim to legitimacy to govern because it fails the moral claim of democracy as a system of government for all. Majority rule which discards the rights of those that have not voted for the government is simply a form of dictatorship.

If elected leaders, even when they command majority support, explicitly exclude the concern of those that had not voted for them, they forfeit any claim to moral legitimacy of democratic rule. It is on that basis that the Westminster Parliament in London voted in 1969 to dismiss the elected government in Northern Ireland (Ulster). That province was carved out of Ireland when the Catholic dominated south of that island gained independence from British rule after the first world war. Slogans of a "Protestant government for a Protestant people" (Bardon 2005, pp. 538-539), was attributed to the first Prime Minister, Lord Craigavon, of Northern Ireland. This majoritarian approach to governance, with some modification, came to characterise the elected governments of Ulster. It was a blot on the post war aspiration for a liberal democracy in Britain. The United Kingdom was a signatory of the Treaty of London aspiring to uphold human rights under the auspices of the newly created Council of Europe. The distasteful antics of the government in Northern Ireland became an embarrassment. The Westminster parliament in London, seat of the UK government, sent troops to the province in 1969, suspending the Stormont parliament there, and imposing direct rule from London.

Whilst no British government has been returned with majority support, certainly not in post war Britain, the Stormont parliament, until it was abolished by decree from Westminster, continued to enjoy majority support amongst the electorate in Northern Ireland. When "British troops were first deployed, in August 1969, it was mainly for the protection of the [minority] Catholics - both in Belfast and Derry - against the sectarian police force of the Stormont regime..." (O'Brien 1971, p. 17).

Schumpeter stated the most obvious of the problems for majoritarian governance: "evidently, the will of the majority is the will of the majority and not the will of the people" (Schumpeter 1950, p. 272). Viewed this way, no democratic norm was violated when the UK government in 1969 sent troop to Ulster (Northern Ireland) imposing direct rule from London by dissolving the local legislature and government elected by the majority in that province.

Stormont parliament bestowed privileges and constrained rights of people for who they were rather than what they were. This type of parliamentary system could not command moral supremacy over authoritarian rule. Respect for the universal nature of human rights has been enshrined in various international proclamations since the middle of the twentieth century. These values, which occasionally clash 
with public opinion, have come to be associated with the idea of democracy. Majoritarian rule fails to satisfy the lofty ideals of democracy.

\section{Rule of Law}

A right to vote does not in itself lead to a right to liberty (Berlin 1958, p. 51). Will of the people and the rule of law guaranteeing liberty of thought and expression might diverge from time to time. Some commentators suggest a stronger role for nonelected institutions, especially the judiciary, at times of social upheavals, to protect democracies against the danger of being metamorphosed into elected dictatorships (Booth 2005). There is a view that it is in the interest of the community to guard the rights of individuals in certain spheres of interaction with the state, for example the right of an accused to due process of the law. These rights might be legislated by an elected parliament, but they need to be defended by an independent judiciary to be protected against the ephemeral currents of public opinion. Some legal philosophers go further (Dworkin 1977). They argue that individuals have moral rights, due process being only one such right, which need not seek validity through legislative sanction and judicial protection. They must be taken as granted in a democracy.

In striking down a law passed by the legislature in West Virginia making it compulsory for school pupils to salute the American flag, US Supreme Court Justice Robert H Jackson took a similar view of rights. He explained:

"The idea of a Bill of Rights was to withdraw certain subjects from the vicissitudes of political controversy, to put them beyond the reach of majorities and officials and to establish them as legal principles to be applied by the courts" (Jackson 1943 quoted in Holmes 1989b, p. 196).

To allow unrestricted domain of choice is to invite cognitive dissonance leading to arbitrary decisions. There is a threat to liberty. There must be some sphere of rights where the individual reigns supreme. The removal of choice to interfere by all others in this sphere of the individual is not only compatible with but also essential for democracy. Justice Jackson in the above judgement places the right not to submit to constant tests of patriotism amongst these essential rights.

Without rights to challenge conventions, whether by words or through the arts, before ballots are cast in the electoral process, reflections on values underpinning choice is not possible. Some of these rights are guarded by non-elected institutions and some are strengthened through other rights like the right peacefully to protest making it possible to appeal to public conscience when rights are violated. How rights are best guarded needs attention, and discourse on democracy must take that challenge on board.

If we are to address the danger of the emergence of elected dictatorships, we need to take on board the necessity of establishing boundaries of choice offered to individuals so as not to intrude on some protected sphere of individual rights. If the majority is given a vote whether to lynch some minority due to their religion, race, appearance, food habit, or whatever, a ghastly outcome could not be ruled out. Results reported in the Milgram experiments in psychology raise concern about the 
propensity of otherwise decent people to inflict extreme cruelty on fellow human beings if instructed to do so by a figure of authority (Milgram 1963). Democracies whether inspired by utilitarian ideas or moral principles of rights grapple with these fears by identifying input filters into the choice set, rejecting "certain classes of desires and preferences", and specifying output filters by rejecting certain outcomes of choice (Goodin 1989, p. 78). These filters are guarded by institutions, for example an independent and sometime supra-national judiciary not subject to the whimsical fluctuations in public opinion. Some of these filters are backed up by legislation, and some are bolstered by social norms discouraging, for example, interference in the operational decisions of law enforcement agencies for the personal or political gains of rulers. Thus, especially in western democracies, social norm require that government is enjoined from using investigative agencies, for example tax authorities and crime investigative bureaus, to shield criminals amongst supporters or to silence the opposition. We judge a democracy not just by its adherence to the principle of unmanipulated elections, but also by the degree of credible protection to rights afforded to dissenters to express their ideas. Existence of a free and vibrant press, and the willingness of the country to submit to an independent judiciary at home and to supra-national jurisdiction over internationally recognized rights of the individual are the marks of a democracy.

After the second world war, there was a recognition of the need also to restrict national sovereignty by setting up supra-national legal bodies, for example the European Court of Human Rights, to ensure liberty. Even a constitutionally independent judicial system within a country, it is now recognized, may require supra-national cover to resist domestic political pressure to suppress rights.

We may have to go further. Even when rights are not violated, preferences of individuals could "sometimes seem "dirty" (Goodin 1989, p. 76) and in need of laundering before being presented for a vote. If a masochist individual wishes to suffer torture, should there be laws against assisting in the torture of a masochist? Articulating and guarding these boundaries need to be under constant discussion to build and keep consensus on rights. These discussions also inform the values which enter the choice function at the ballot box.

\section{Censoring of Choice}

Apart from the question of rights, there is another reason for censoring, or at least sequencing, choice offered to the electorate. "To avoid destructive conflicts, we suppress controversial themes" (Holmes 1989a, p. 19). Confidence building measures in diplomacy start with topics on which easy agreements can be reached. International and national declarations on human rights provide one approach. International declarations bypass questions of national sovereignty in formulating aspirations for identifying universal moral values. National declarations sometimes enshrined in constitutions come to define national aspirations. Aspirations once stated get detailed meaning through case law over time. The declaration by the founding fathers at US independence, many of them slave holders, that "all men are created equal" began to 
be given meaning against racial discrimination only through case law in the second half of the twentieth century.

Themes that arouse primordial feelings of religious or national identity are not easily amenable to rational discourse, and they need to be parsed to become amenable to rational discourse. Discourse based on a scalar view of identity defining people obfuscates matters where evidence becomes less important than doctrine (Sen 2006). We have multiple identities as members of various groups (Sen 2006). ${ }^{5}$ Parsing the choice set is essential for rational discourse.

John F Kennedy in his presidential campaign resolved the problem of deep suspicion of Roman Catholics by the numerically more important protestant voters by announcing his unconditional allegiance to the state over the dictates of his faith. Then the discussion could proceed to issues about economic wellbeing, foreign policy and the like.

A visceral fear of Catholics characterized American politics for more than a 100 years. "In 1875, a decade after accepting General Lee's surrender at Appomattox, President Ulysses S. Grant publicly warned that Catholicism might prove as divisive in American society as the Confederacy" (McGreevy and Appleby 2010). Fearful of his political agenda being hijacked by this single issue, Kennedy made the doctrine of the separation of church and state a central message in his quest for the White House. Early in the presidential campaign season, he appeared before a gathering of Protestant ministers to declare that he took seriously the separation of his faith from his political agenda. In making decisions on governance, he would ignore the dictates of the church. ${ }^{6}$ This agenda restriction, for example removing the discussion about the religious affiliation of Kennedy in our example, is a common feature of decision making. "He who determines what politics is about runs the country" (Bachrach and Baratz 1962, p. 948).

\section{Choice Over Policy or Choice Over Outcome?}

An exclusive focus on vote counting misses an important point: what is being counted? Voting data do not tell us why the choice that is marked on the ballot paper is made. What was the reasoning behind that choice? Even a clear win for a candidate is no mandate for policies espoused by the victor because the reasoning is unknown. Wise governments examine the reason why they won, and reflect on

\footnotetext{
5 "In our normal lives, we see ourselves as members of a variety of groups - we belong to all of them. The same person can be, without any contradiction, an American citizen, of Caribbean origin, with African ancestry, a Christian, a liberal, a woman, a vegetarian, a long-distance runner, a historian, a schoolteacher, a novelist, a feminist, a heterosexual, a believer in gay and lesbian rights, a theatre lover, an environmental activist, a tennis fan, a jazz musician, and someone who is deeply committed to the view that there are intelligent beings in outer space with whom it is extremely urgent to talk (preferably in English). Each of these collectivities, to all of which this person belongs, gives her a particular identity." (Sen 2006, prologue, Kindle edition).

6 A copy of the lecture can be found at http://www.npr.org/templates/story/story.php?storyId=16920600 (downloaded 07 August 2017).
} 
the potential disconnect between the outcome expected and policies they chose at the ballot box. This becomes a more difficult exercise in referendum led democracies because referendums present multiple components of an issue as a scalar choice.

Choice can be clouded by issues not on the ballot. For example, an electorate disillusioned with the performance of government on one set of issues might vote against government proposal in a referendum concerning an altogether different issue. An analysis of election statistics published by the House of Commons suggests that there is a protest vote against the party in power at byelections when a seat is vacated due to resignation or death (see Table 12 Audickas et al. 2017). A third party which is unlikely to form a government, in Britain it often used to be the Liberal Democrats in the past, can benefit. Observed choice may be conflated with preference if the underlying reason for choice is not investigated (Sen 1973). If that missing information is absent in the formulation of government policy, the outcome may not command public support.

Consider an example. Suppose that voters wish to see a reduction in the crime rate and vote for a policy which they think will diminish crime. Suppose further that the outcome of the policy is quite the reverse. They might still blame the government, even if it enacts into policy the voters' choice, for their disappointment. Individuals cannot be held responsible to gather specialist knowledge, but government can be held responsible for lack of expertise. "Consenting to a process is not the same thing as consenting to the outcomes of the process" (Coleman 1989, p. 197).

For the purposes of illustrating the idea further, consider the following numerical exercise taken from Haslett (1985). He constructed the exercise illustrating a different issue, but the example is apposite here.

Suppose that society comprises three individuals-Hilda, Matilda and Zelda. They have to decide at an election on the criterion for the choice of policy. There are two criteria: applying the Rawlsian Difference Principle or applying the Utilitarian Principle in deciding on policy. The Difference Principle entails that a policy which makes the worst off better off should be chosen (Rawls 1972, pp. 75-80) and the Utilitarian Principle entails that policy should aim to maximise the aggregate utility of all concerned. The numerical values of the two alternatives are as follows. Policy Alternative 1 provides Hilda, Matilda and Zelda with 300, 200, 500 utils, respectively. Policy Alternative 2 provides Hilda, Matilda and Zelda with 5000, 3000, and 50 utils, respectively. Utilitarian considerations entail the choice of Alternative 2. It produces an aggregate social utility of 8050 compared to only 1000 under Alternative 1. However, the person who is worst off under Alternative 1 obtains 200 utils. This is better than 50 utils available under Alternative 2. The Difference Principle suggests Alternative 1 .

Now consider a case of sequential applications of policy between elections. Suppose that at some initial date, the date of the election, voters choose the Difference Principle (DP) over the Utilitarian Principle (UP). They apply their chosen rule in three sequential policy choices as outlined in Tables 1,2 and 3 below.

Let us look at the consequence of choosing policy DP at each point in the sequence, in conformity with the ex ante preference for that policy. Table 4 gives 
Table 1 Utility distribution under choice set 1

Table 2 Utility distribution under choice set 2

Table 3 Utility distribution under choice set 3

Table 4 Final outcome dictated by the DP criterion

Table 5 Final outcome dictated by the UP criterion

\begin{tabular}{lllllr}
\hline Person & \multicolumn{2}{l}{ Policies on offer } & & \multicolumn{2}{l}{ Policy choice } \\
\cline { 2 - 3 } \cline { 5 - 6 } & Alternative 1 & Alternative 2 & & DP & UP \\
& & & & Alt 1 & Alt 2 \\
\hline Hilda & 25 & 120 & & 25 & 120 \\
Matilda & 20 & 60 & & 20 & 60 \\
Zelda & 15 & 10 & & 15 & 10 \\
Total & 60 & 190 & & 60 & 190 \\
\hline
\end{tabular}

\begin{tabular}{llllll}
\hline Person & \multicolumn{2}{l}{ Policies on offer } & & & \multicolumn{2}{l}{ Policy choice } \\
\cline { 2 - 3 } \cline { 5 - 6 } & Alternative 1 & Alternative 2 & & DP & UP \\
& & & & Alt 1 & Alt 2 \\
\hline Hilda & 70 & 10 & & 70 & 10 \\
Matilda & 25 & 65 & & 25 & 65 \\
Zelda & 25 & 55 & & 25 & 55 \\
Total & 120 & 130 & & 120 & 130 \\
\hline
\end{tabular}

\begin{tabular}{lllllr}
\hline Person & \multicolumn{2}{l}{ Policies on offer } & & & \multicolumn{2}{l}{ Policy choice } \\
\cline { 2 - 3 } \cline { 5 - 6 } & Alternative 1 & Alternative 2 & & DP & UP \\
& & & & Alt 1 & Alt 2 \\
\hline Hilda & 45 & 50 & & 45 & 50 \\
Matilda & 25 & 5 & & 25 & 5 \\
Zelda & 15 & 45 & & 15 & 45 \\
Total & 85 & 100 & & 95 & 100 \\
\hline
\end{tabular}

\begin{tabular}{llllc}
\hline Names & First set & Second set & Third set & Total outcome \\
\hline Hilda & 25 & 70 & 45 & 140 \\
Matilda & 20 & 25 & 25 & 70 \\
Zelda & 15 & 25 & 15 & 55 \\
Total & 60 & 120 & 85 & 265 \\
\hline
\end{tabular}

\begin{tabular}{lcccl}
\hline Names & First set & Second set & Third set & Total outcome \\
\hline Hilda & 120 & 10 & 50 & 180 \\
Matilda & 60 & 65 & 5 & 130 \\
Zelda & 10 & 55 & 45 & 110 \\
Total & 190 & 130 & 100 & 420 \\
\hline
\end{tabular}


the outcome. Then compare that outcome with what might have been, as shown in Table 5, if choices at each step were dictated by the utility maximisation criterion.

Comparing the final outcomes in Tables 4 and 5, we note that the application of the difference principle, choosing policies which maximise the utility of the worst off, leads to the worst off person getting only 55 utils. If the choices were instead based on the utility maximisation criterion, the worst off person would have obtained 110 utils. Policy choices based on ex ante preference for policy, in this case, leads to an ex post outcome which is contrary to the voters' wishes.

\section{Referendums}

The above type of mismatch between policy choice and expected outcome can be particularly stark in a referendum, especially when there is a binary choice on a complex issue. Schumpeter mentions crime as one of those complex issues on which seeking inflexible prescriptions from the public in referendums are inappropriate.

"Take for example the case of so bulky and so technical a measure as a criminal code. The democratic method will apply to the question whether or not a country is to have such a codification at all. It will also apply to certain 'issues' that the government may choose to select for political decision which is more than formal - for instance, whether certain practices of labor or employers' associations should or should not be considered criminal. But for the rest, government and parliament will have to accept the specialists' advice whatever they may think themselves." (Schumpeter 1950, p. 292).

An example is to be found in a story reported in the New York Times on the 5th of March 1995 about the freak outcome of a referendum held in California on sentencing guidelines for convicted criminals. The proposal was to mandate a prison term for at least 25 years before parole could be considered after the third conviction of a repeat offender. The voters were presented with a binary decision: yes or no to the proposal. The referendum question did not distinguish between violent and nonviolent crimes. The campaign took place in the background of press reports about a murder committed by a culprit who had previous convictions for violent crimes. Emotions were running high. Professionals having experience in the maintenance of law and order were skeptical about the wisdom of imposing such an inflexible mandate on the judiciary. Soon after the referendum proposal was carried, a young pizza thief, who had helped himself to a slice of pizza, was caught in the net. He had previous convictions.

Hardin (2009, pp. 68-69) provides many examples of perverse outcomes of referendums. Here we shall look at the Brexit referendum in the United Kingdom held in June 2016. It took place in the background of press reports about many of the failures of the European Union, and there are many. The Maastricht Treaty was drawn up by a political class which failed to listen to even its own advisors about the need for non-market institutions to cater for regional imbalances (Chakravarty 2016a). This failure was compounded by the introduction of a single currency conceived as a monetarist experiment then in vogue in the corridors of power, and introduced at a 
time when financial regulations did not keep up with emerging techniques of speculation which transmitted and amplified financial bubbles across national frontiers. The inevitable outcome, the international credit crunch, exacerbated EU-specific crises like the one in Greece. The EU was deservedly shown up in an unfavourable light in the press coverage of problems in the eurozone. "Unfortunately, while finance has gone global, its regulations remains a national affair. ... as financial crises grow in frequency and severity, they will inflict social and political instability and ultimately breed a backlash against globalization" (Roubini and Mihm 2010, p. 300).

If public confidence in western democracy is not to be eroded, major reform is needed, and not just of the EU institutions. Countries like the UK, a member state which remains outside the euro, and the US also need to wake up to voter alienation by addressing the distributional consequences of globalisation and technical change (Sennett 1998). The fiscal pressure of the rising cost of bank rescue and reliance on austerity measures bring into sharp focus the failure of globalized finance as it has evolved since the 1980s. What is needed is to address the regulatory issues in concert with trading partners instead of relying exclusively on austerity measures putting public services under increasing strain. Government complacency about crossborder cooperation needed to regulate the international financial system, and stories of the EU leaders' failure to engage in reforming the financial system, that the Brexit referendum was held. The referendum was an opportunity for the public to vent disillusionment with the orthodoxy of globalization.

It is in the very nature of a referendum that complex issues are not clarified, as noted by Schumpeter above. The binary choice placed before the electorate in the referendum on EU membership was not amenable to rational discourse over economic impacts because the only sure comment that could be made was that Brexit would create huge uncertainty. The terms of exit were not on the ballot paper. They were not known except in terms of vague and meaningless slogans about taking back control. It was not even discussed who was to take back control, parliament or the executive? Voters were asked to choose in darkness about the terms of exit, the terms which could have an enormous impact on their lives. ${ }^{7}$ Thus the discourse focused on nostalgia about an imagined past. Doctrines of identity, which are not amenable to rational discourse because they are moved by feelings and not hard evidence, arouse extreme passions. The 'evidence' comprises selective memories of a collective past. The Czech born German speaking American political scientist Karl Deutsch once described discussion of national identity focusing on excluding the

\footnotetext{
7 For example, voters were not told because the government did not know if the UK would come out of Euratom, the agency for cooperation and regulation of safety in nuclear materials. Newspaper reports now suggests that a leading figures in the Leave campaign, Dominic Cummings, now describes "Theresa May's government as 'morons' over plans to drag Britain out of Euratom” (Payne 2017). The voters did not know the implication of a vote on the peace process in Northern Ireland. Government has made a commitment, entered into in the peace process to end sectarian killings which had blighted the history of Ulster for much of the twentieth century, to a border between Ulster and the Republic of Ireland being free of check posts. How could an open border be maintained if movements of goods between the EU and the UK become subject to customs control? No one could tell.
} 
other as a discourse conducted by ".... group of persons united by a common error about their ancestry and a common dislike of their neighbours" (Deutsch 1969).

Many voters may have discounted economic problems of exit-reliable calculations of economic gains and losses, let alone the distribution of pain and gain, could not be undertaken with any degree of certainty because the terms of exit were unknown at the time of the referendum-and it is only now dawning on them the potential risk to economic stability depending on the terms of exit which were not on the ballot papers.

This is a special case of conflict between ex ante choice and ex post evaluation of that decision. Democracy cannot surely forbid such re-evaluation simply because a vote was cast in the dark? In a representative form of government, policies comprising the winning platform are evaluated for coherence before implementation. ${ }^{8}$ Yet referendum-based politics make it difficult to change course because the period of remit of a referendum result is ill-specified. The post-referendum slogan by both the major parties in the UK is that the decision of the electorate to leave the EU, taken in darkness about the terms of exit, must be carried out even on terms which could not have been imagined at the time of the vote as a mark of respect for democracy. This is like arguing that a government once elected must be allowed to govern, even if its policy platform turns out to be a fantasy, without having to submit ever again to elections. Referendums do not clarify the choice set in elections, and they do not enhance the aspiration of democracy that people must have a say in how they are governed.

This is in contrast with the idea of periodic general elections to elect representatives to govern. There is a clear path for abandoning support for a policy on which the winning representatives are committed when it turns out to be unworkable in the course of a parliament. The electorate can choose to dismiss a government if the outcome of policies for which voters had cast their ballot turn out to be worse than anticipated.

The underlying logic of periodic tests of opinion is that it is rational to change views if antecedent ordering of priorities was not based on all relevant information needed to make the calculations of policy consequence. It is not even unprecedented in a democracy for a government upon election to re-order priorities hinted at the hustings because of a realisation of unanticipated consequences of policy. ${ }^{9}$ Citing the writings of such politically diverse authors as Lipset (1960) and Habermas (1975), Przeworski (1991, p. 14) points out that "ex post evaluations modify the ex ante commitments". Asking the voters to acquire specialist knowledge is an abdication of the responsibility of government to demonstrate competence in seeking advice from specialists to deliver the outcome that the electorate desires. ${ }^{10}$

\footnotetext{
${ }^{8}$ See the discussion in Appendix B about the rise of fiscal deficit in the UK under Mrs. Thatcher who came to power having campaigned for a reduction. However, reduction was not compatible with some of the other policies also put forward at election time.

9 I have argued this point elsewhere discussing the referendum on UK membership in the EU, and the argument is repeated in Appendix B.

${ }^{10}$ In our view, it is not the job of the voter to familiarize herself with specialist subjects any more than it is the job of the patient to acquire specialist medical knowledge before choosing a doctor. The patient reserves the right to question the doctor's competence if the treatment turns out to be wrong.
} 
Referendums do not provide the electorate with an effective voice because, by taking issues in isolation referendums do not contribute to reasoned choice. Referendums deny voice by blocking new information from being considered. If participatory democracy means more referendums to increase public engagement with democracy, it is tracking the wrong solution by conflating democracy as a utility maximization exercise under an ill-defined information set.

\section{Conclusions}

The challenges to democracy from populist movements offering simplistic solutions to voters disillusioned with democracies which suffered a jolt to selfconfidence following the credit crunch in 2007 cannot be addressed purely by focusing on the voting system, either by examining the rules for aggregating individual choice expressed through the ballot box or by burdening the electorate with more elections as in referendums on complex policies. In our view, the dangers to democracy are better addressed by focusing attention on the design of institutions which can thwart the rise of an elected dictatorship, and by strengthening representative governance by creating room for reflection on the current economic model which has failed to address the anxieties (Sennett 1998) of the electorate about technical change and globalisation. The outcome of the Brexit referendum is a warning. Once that genie of nationalism begins to get released in one country after another, international cooperation will become difficult to make globalisation an attractive electoral proposition.

The role of non-elected institutions in protecting democracy cannot be emphasized too much (Booth 2005). The impact on democracy of the rise of autocratic leaders in Russia, Turkey and the United States have been different from each other because there are institutional differences. American democracy is strengthened by checks on presidential powers which have evolved since the Nixon era to shield the operational decisions of non-elected bodies such as the Federal Bureau of Investigation from presidential diktat. It takes time to appoint new judges to do the president's bidding. Even the judges that a president appoints cannot be guaranteed fully to cooperate in egregious attempts to unleash investigative agencies to harass opposition politicians. Norms of political discourse constrain wholesale muzzling of the press. These norms matter. Elections alone cannot provide good governance, let alone good democratic governance. Witness Turkey and Russia.

Acknowledgements Helpful comments from David Hojman, Manfred Holler and Karl-Heinz Toedter are gratefully acknowledged without implicating them in any errors of mine.

\section{Compliance with Ethical Standards}

Conflict of interest There is no conflict of interest and I have received no external funding for this research. 
Open Access This article is distributed under the terms of the Creative Commons Attribution 4.0 International License (http://creativecommons.org/licenses/by/4.0/), which permits unrestricted use, distribution, and reproduction in any medium, provided you give appropriate credit to the original author(s) and the source, provide a link to the Creative Commons license, and indicate if changes were made.

\section{Appendix A: How to Count the Election Outcome?}

Vote counting rules can have a critical impact of what is declared as the voters' choice. Donald Trump won against his main rival Hilary Clinton having secured fewer votes than her. A similar anomaly was observed in 2000 when George W. Bush defeated Al Gore. The outcomes of these elections have generated interest in the voting aggregation rules used in the US presidential election. For example, calculations using US voting data by Maskin and Sen (2017) in the 2016 presidential election suggest that removal of certain anomalies, for example third party votes are now wasted, in the sequence of selecting the presidential candidate would have denied Donald Trump the key to the White House. However, it is accepted that no vote counting rule is free of the anomaly that a candidate who is less liked could defeat a candidate who carry greater support. Now consider the recent German elections. If the first past the post system of electing members of parliament in London were adopted as the counting rule for the Bundestag in Germany, Angela Merkel's CDU-CSU combination would have comfortably retained power. Parliament in Britain comprises members elected by single member constituencies under the plurality rule of vote counting. The CDU-CSU combination won 231 out of 299 Constituency seats in 2017, not far behind the 236 out of 299 in the 2013 election. Merkel would have been declared the overwhelming winner in 2017. The first past the post system of selecting members of parliament has come under special scrutiny in the UK in recent years because of the lack of correspondence between the share of seats in parliament for a party and the share of the votes cast for it. Devolved assemblies in Ulster, Scotland and Wales use other methods to address the problem. They carry their own anomalies (Woodall 1986, 1987). In Wales and Scotland, vote counting rules are closer to the AV system used in selecting members of the Bundestag. The single transferable vote (STV) is used in Ulster. Cases could arise in the Welsh Assembly elections where increase in the support for a party would paradoxically become problematic for the party (Altunbas et al. 2002). Bogdanor (1984, p. 41) provides more examples of anomalies in the AV and STV system used elsewhere, for example, in Australia and the Republic of Ireland. In 1977, the combined share of votes (first and second preference votes) for the Australian Liberal Party was a meagre 38.3\% of the votes cast. They commanded $53.2 \%$ of the seats, and ousted Labor from power although Australian Labor had obtained a larger per cent of the votes. In the Republic of Ireland, where the single transferable vote formula is applied, in both 1965 and 1969 Fianna Fail party formed the government having managed to secure only a plurality of the first preference votes. There are also conceptual difficulties in relating proportionality of votes with the idea of proportionality of power. A paper by Saari and Sieberg (2001) presents an interesting analysis of the statistical aspects of bundling a number of issues, for example in a referendum, presented as a single dimensional choice. 


\section{Appendix B: Unintended Outcomes}

I have argued this point elsewhere discussing the referendum on UK membership of the EU casting doubts about the democratic merit of holding a referendum on EU membership in Britain (Chakravarty 2016b). The argument, some of it is verbatim, is repeated here. A difference between participating in parliamentary elections in a system of representative government and voting in referendums is that the voter imposes on herself and the rest of society a greater burden of any unintended and unwelcome consequences of the outcome of a referendum. These consequences may not become apparent until after the results are known but the winning policy cannot be reversed without holding another referendum. This is especially so when the status quo is severely jolted in pursuit of identity politics, which sit uneasily with economic reality. In electing representatives to govern, the voter has the luxury of voting for government on a policy platform, but judging the government on consequences of that platform. Casting a vote for candidates espousing, for example, a tough stance on immigration does not constrain the voter from criticizing a government thus elected if the availability of medical care is compromised due to lack of qualified staff. In representative democracy, government has some leeway for manoeuvre if the consequences of living with policies espoused at the hustings prove intolerable. Referendums do not allow that leeway. Mrs. Thatcher secured a parliamentary majority in 1979 on a policy platform comprising, inter alia, a vow dramatically to reduce the share of government expenditure in the GDP which then stood at $45 \%$. Notwithstanding this harsh rhetoric, government expenditure and its share in the GDP continued to increase in the initial years driven by unforeseen fiscal pressures of a sudden and sharp rise in unemployment. The ratio finally came down, but only to $40 \%$ of the GDP, when she left office a decade later. This is not to say that representative governance entails a cavalier disregard of promises made at election time but to suggest that the promises need to be interpreted in context. The context is the need for elected representatives, once in government, to engage with complex technical issues and tedious details of policy to ensure coherence to avoid chaos. That is why stable democracies choose representative forms of government, and governance by referendum is shunned.

\section{References}

Altunbas, Y., Chakravarty, S. P., \& Steffen, F. (2002). A note on the electoral rules for the Welsh Assembly. Public Choice, 111, 185-193.

Arblaster, A. (1987). Democracy. Milton Keynes: Open University Press.

Armingeon, K., \& Guthmann, Kai. (2014). Democracy in crisis? The declining support for national democracy in European Countries, 2007-2011. European Journal of Political Research, 53(3), 423-442.

Arrow, K. J. (1963). Social choice and individual values. London: Yale University Press.

Audickas, L., Hawking, O., \& Cracknell, R. (2017). UK election statistics 1918-2017. Briefing Paper no CBP 7529. London: House of Commons (downloaded 23/08/2017). http://researchbriefin gs.parliament.uk/ResearchBriefing/Summary/CBP-7529. 
Bachrach, P., \& Baratz, M. S. (1962). Two faces of power. American Political Science Review, 56 (4), 947-952.

Bardon, J. (2005) A history of ulster. Belfast: Blackstaff Press. https://en.wikipedia.org/wiki/A_Protestant _Parliament_for_a_Protestant_People. Accessed 27 Jul 2017.

Becker, G. (1973). The economics of discrimination (2nd ed.). Chicago: Chicago University Press.

Berlin, I. (1958). Two concepts of liberty. Oxford: Clarendon Press.

Bogdanor, V. (1984). What is proportional representation?. Oxford: Martin Robertson.

Booth, C. (2005) Now we need judges more than ever (edited extract of the 19th Sultan Aziz Lecture Shah law lecture delivered by Cherie Booth published in The Guardian. https://www.theguardia n.com/uk/2005/ju1/28/july7.politics1.

Chakravarty, S. P. (2008). Neo-conservative or neo-liberal? Homo Oeconomicus, 25(3-4), 381-397.

Chakravarty, S. P. (2016a). Need for non-market institutions for inter country transfers: Referendum lesson. Downloaded 21 October 2017. https://blogs.cardiff.ac.uk/wiserd/2016/07/06/need-for-nonmarket-institutions-for-inter-country-transfers-referendum-lesson/.

Chakravarty, S. P. (2016b). Referendum: Decision under uncertainty (Downloaded 30 April 2018). http:// www.fortank.com/blog/38-referendum-decision-under-uncertainty.

Chomsky, N. (2006). Failed states: The abuse of power and the assault on democracy. London: Penguin.

Coleman, J. (1989). Rationality and the justification of democracy. In G. Brennan \& L. E. Lomasky (Eds.), Politics and process. Cambridge: Cambridge University Press.

Deutsch, K. (1969). Nationality and its alternatives. New York: Knopf.

Downs, A. (1957). An economic theory of democracy. New York: Harper.

Dworkin, R. (1970). Taking rights seriously. New York Review of Books, 15(11) (Dec 17 issue).

Dworkin, R. (1977). Taking rights seriously. Cambridge, MA: Harvard University Press.

Elster, J. (1989). Nuts and bolts. Cambridge: Cambridge University Press.

Fishburn, P. (1974). Paradoxes of voting. American Political Science Review, 68(2), 537-546.

Forder, J. (2011). Case against proportional representation. Oxford: Oneworld Publications.

Frey, B. (1994). Direct democracy: Politico-economic lessons from Swiss experience. American Economic Review (papers and proceedings), May issue, pp. 338-342.

Frey, B. (2017). Proposals for a democracy of the future. Homo Oeconomicus, 34(1), 1-9. (April issue).

Goodin, R. E. (1989). Laundering preferences. In J. Elster \& A. Hylland (Eds.), Foundations of social choice theory. Cambridge: Cambridge University Press.

Habermas, J. (1975). Legitimation crises. Boston: Beacon.

Hardin, R. (2009). How do you know? The economics of ordinary knowledge. Princeton, NJ: Princeton University Press.

Haslett, D. W. (1985). Does the difference principle really favour the worst off? Mind, 94(373), 111-115.

Hirschman, A. O. (1994). The on-and-off connection between political and economic progress. American Economic Review, 84(2), 343-348.

Hobsbawm, E. J. (1962). The age of revolution. New York: Mentor.

Holmes, S. (1989a). Gag rules on the politics of omission. In J. Elster \& R. Slagstad (Eds.), Constitutionalism and democracy. Cambridge: Cambridge University Press.

Holmes, S. (1989b). Pre-commitment and the paradox of democracy. In J. Elster \& R. Slagstad (Eds.), Constitutionalism and democracy. Cambridge: Cambridge University Press.

House of Commons. (2014). 4th report of session 2014-15 of political and constitutional reform committee, HC 232. Downloaded on 15 October 2017. https://publications.parliament.uk/pa/cm201415/ cmselect/cmpolcon/232/232.pdf.

House of Lords. (2010). 12th report of session 2009-10 of select committee on the constitution, HL Paper 99. Downloaded on 15 October 2017. https://publications.parliament.uk/pa/ld200910/ldsel ect/ldconst/99/99.pdf.

Keynes, J. M. (1963). The end of laissez faire. Essays in persuasion. London: Macmillan.

Lacroix, J. (2017). Steam democracy up! Industrialization-led opposition in Napoleonic plebiscites. Centre Emile Bernheim Working Paper No 17/022, Sept.

Ladha, K. K. (1992). The Condorcet jury theorem, free speech and correlated voting. American Journal of Political Science, 36(3), 617-634.

Laski, H. (1962). Introduction to politics. New York: Unwin.

Leonard, D., \& Mortimore, R. (2001). Elections in Britain: A voter's guide. London: Palgrave.

Levin, J., \& Nalebuff, B. (1995). An introduction to vote-counting schemes. Journal of Economic Perspectives, 9(1), 3-26.

Lipset, S. M. (1960). Political man. Garden City, NY: Doubleday. 
Maskin, E., \& Sen, A. (2017). The rules of the game: A new electoral system. New York Review of Books, 64(1) (January issue).

McGreevy, J. T., \& Appleby R. S. (2010). Catholics, muslims, and the mosque controversy. New York Review Daily (Sept 30 issue). https://www.nybooks.com/daily/2010/08/27/catholics-muslimsmosque-controversy/.

Milgram, S. (1963). Behavioral study of obedience. Journal of Abnormal Psychology, 67(4), 371-378.

Mills, C. W. (1977). The sociological imagination. Harmondsworth, Middlesex: Penguin.

Mishan, E. J. (1982). Introduction to political economy. London: Hutchinson.

Nurmi, H. (1998). Voting paradoxes and referenda. Social Choice and Welfare, 15(3), 443-454.

O'Brien, C. C. (1971). Violence in Ireland: Another Algeria? New York Review of Books, 17(4), 17-19. (Sept 23 issue).

Payne, A. (2017). Chief Brexit campaigner calls Tory government 'morons' for planning to leave EU nuclear treaty. Business Insider July 10 Downloaded 21 October 2017. http://uk.businessinsider .com/chief-brexit-campaigner-calls-tory-government-morons-for-planning-to-leave-eu-nuclear-treat y-2017-7.

Przeworski, A. (1991). Democracy and the market. Cambridge: Cambridge University Press.

Rawls, J. (1972). A theory of justice. Oxford: Oxford University Press.

Roubini, N., \& Mihm, S. (2010). Crisis economics: A crash course in the future of finance. London: Allen Lane.

Saari, D. G., \& Sieberg, K. K. (2001). The sum of parts can violate the whole. American Political Science Review, 95(2), 415-433.

Särlvik, B., \& Crewe, I. (1983). Decade of de-alignment. Cambridge: Cambridge University Press.

Schumpeter, J. A. (1950). Capitalism, socialism, and democracy (3rd ed.). New York: Harper and Row.

Sen, A. (1973). Behaviour and the concept of preference. Economica, 40, 241-259.

Sen, A. (2002). Rationality and freedom Cambridge. Cambridge, Mass: Belknap Press.

Sen, A. (2006). Identity and violence: Illusion of destiny. London: Penguin. (consulted Kindle edition).

Sennett, R. (1998). The corrosion of character: The personal consequences of work in the new capitalism. New York: Norton.

Woodall, D. R. (1986). How proportional is proportional representation? The Mathematical Intelligencer, $8(4), 36-46$.

Woodall, D. R. (1987). An impossibility theorem for electoral systems. Discrete Mathematics, 66, 209-211. 